\title{
The Case For Arts Education As A Required Component Of An Accounting Student's College Education
}

J. David Mason, (Email: jmason@siue.edu), Southern Illinois University, Edwardsville Rebecca Mason Stefoff, Music Consultant, Huntington, West Virginia

\begin{abstract}
A recent study has highlighted the importance of student perceptions of the accounting profession and the resultant self-selection process. This self-selection process may result in students selfselecting into the accounting area who are deficient in the essential qualities for success in the modern accounting profession. Warnock (1996) reports that among $1^{\text {st }}$ year accounting students a still pervasive image of the accountant is that it is not particularly important to have either imagination or verbal qualities or communication or critical thinking skills and thus students who are weak in the above qualities often self-select into accounting as a major. The purpose of this paper is to introduce into the accounting literature the results of an emerging body of research that suggests arts education can enhance or help accounting students overcome these deficiencies.
\end{abstract}

\section{Introduction}

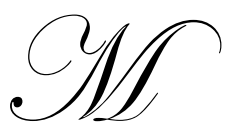

any people regard the actual participation in the Arts, such as playing a musical instrument, reserved for a "gifted" few, yet there is a growing body of research that suggests sustained and continuous arts education has non-arts benefits in human development. In fact, this body of research suggests that the study of music may aid in the development of certain cognitive attributes. The cognitive attributes that benefit from music education have also been cited as necessary for the 'new' accountant of the $21^{\text {st }}$ century. Research has also suggested that the study of theatre has important benefits in the development of interpersonal skills as well. The interpersonal skills that are posited to develop from theatre education are similar to those that are considered necessary to success as an accounting professional. Other research suggests that students self-select into accounting that are deficient in these same cognitive and interpersonal attributes. The purpose of this paper is to discuss some of the findings of this research on non-arts benefits in human development and to propose that accounting students be required to participate in the arts as a regular part of their fulfillment of their college education requirements. Such participation is posited to assist accounting students in overcoming deficiencies in cognitive and interpersonal areas that are important to success as a $21^{\text {st }}$ century accountant.

\section{Attributes of the successful accountant}

The business community is currently experiencing a period of unprecedented change. These changes are being driven by many factors, including rapidly changing information technology, globalization of the business environment, and related increases in complexity of the business environment. In response to this changing business environment, it is argued that accounting education must change to provide the accounting practitioner community with new accountants that have what are perceived to be the proper characteristics for success in this new environment. In other words, the academic accounting community is seeking to respond to an apparently broadbased view in the accounting profession that today's accounting students (the newly qualified professionals) are deficit in certain broad qualities deemed desirable (e.g., Accounting Education Change Commission (AECC) 1990, International Federation of Accountants 1994. Perspectives on Education: Capabilities for Success in the Accounting Profession 1989). These characteristics may be summed under the headings of creativity, life long learning (self discipline), multi-level thinking, and interpersonal skills. 
For example the Bedford Committee Report [AAA, 1986, pp. 179-180] states that:

"The comprehensive professional accounting education program... must develop in students an understanding of the nature and skills of logical reasoning; a capacity for creative thinking and problem-solving; an appreciation of ethical standards and conduct; and a facility with the methods of effective communication and interpersonal relations."

In 1989, the (then) largest 8 international accounting firms in the US identified the 3 essential qualities needed by entry level accountants as (1) intellectual skills (e.g., creative problem solving and dealing with unfocused facts and ethical issues), (2) interpersonal skills, and (3) communication skills (Perspectives, 1989).

\section{Attributes of the typical accounting student}

A more recent study has highlighted the importance of student perceptions of accounting and the resultant self-selection process that may be resulting in students self-selecting into the accounting area who are deficient in the essential qualities for success as listed above. Two instruments were used in the study. One instrument listed the qualities or attributes that might or might not be considered of importance to new accountants. Each participant was asked to rate each attribute on a 5-point scale. The second instrument was a series of paired statements, with each statement representing one of the characteristics. The statements were to represent attributes of 2 students applying for an entry level accounting position. Participants in the study were asked to play the role of a recruiter and select the student they would most likely choose for the position, assuming the 2 students represented by the statements were identical on all other dimensions.

One group of participants included campus recruiters for the then Big Six accounting firms. A second group of participants were $1^{\text {st }}$ year accounting students and a third group of participants were 3rd year accounting students. Warnock (1996) reports that contrary to the perceptions of recruiters, among 1 st year accounting students who participated in the study, a still pervasive image of the accountant is that it is not particularly important to have imagination, verbal qualities, communication skills, or critical thinking skills to be successful as an accountant. Although somewhat moderated, this image of the accountant was also found to be prevalent among the $3^{\text {rd }}$ year accounting students.

Warnock concludes the article by stating that "what is particularly distressing, given the importance which professional accountants attach to communication skills, is the idea that students may elect to study accounting because it is perceived to make fewer communication demands than other fields of study (Stanga and Ladd, 1990, p.182). The study provides additional evidence that students who are weak in the above qualities not only self-select into accounting as a major but may resist attempts to help them overcome such weaknesses (Geary and Rooney (1993)).

One of the purported reasons for the move to the 150-hour education requirement (this requirement has now been adopted by the majority of state accounting licensing boards) for CPA's was the above-mentioned recognition that accountants need a broader based education to prepare them for their role as accounting professionals in an increasingly global environment. However, requirements as to the type of courses that would best fulfill the stated objective are not specified. Anecdotal evidence suggests that accounting students have responded by seeking to fulfill the 150-hour rule with graduate work that is primarily of a technical accounting nature. Although this additional technical training is valuable in providing students with a stronger conceptual and practical foundation, it may not result in a more 'rounded' graduate, since human nature tends to avoid exposure to areas of deficiencies. Thus, while the accounting student who has completed the 150 hour requirement with a graduate degree in accounting has embraced the notion of additional technical training in accounting (since it compliments and enhances the successes they have already demonstrated in their undergraduate accounting curriculum), they may have avoided coursework in areas that they have not valued and at which they may not be very successful (such as intellectual, interpersonal, and communication skills). This argument would suggest that without specific requirements as to the type and content of courses to be taken, the 150-hour requirement might be ineffective in accomplishing the purpose for which it was enacted. 
A second rather interesting attempt to meet the developmental needs of accounting students in these targeted areas has been to place the burden on accounting faculty to include training in interpersonal, intellectual, and communication skills within the context of the accounting courses themselves. This attempt may be seen in programs with titles such as 'writing across the curriculum.' The shortcomings of such an approach are student resistance as mentioned above, also faculty resistance. Most accounting doctoral programs do not prepare accounting faculty to teach interpersonal and communication skills, rather doctoral programs emphasize the technical how to's of accounting, as well as the how to's of survival in academia, i.e., publishable research. The result is accounting faculty who are well prepared to perform publishable research and adequately prepared to teach the technical aspects of accounting, but who do not have the expertise to teach intellectual, communication and interpersonal skills. Furthermore, accounting faculty may also be prone to the same self-selection bias as their students. Thus, this attempt to place this obligation upon the accounting faculty may lead to minimal success at best. Furthermore, time spent on these skills reduces time available in accounting classes for preparing accounting students for the technically complex and demanding aspects of being an accounting professional. This would result in students leaving academia ill prepared for the technical aspects of professional accounting. Accounting faculty may also resist such moves since the devotion of time and energy to develop the expertise to teach such skills may detract from their survival in accounting academia, i.e., the performance of publishable research.

An alternative that would seem to be rather straightforward would be to first seek out professionals in other academic disciplines who have the training and expertise, and the courses and course content to educate our accounting students in these important areas and then make such coursework a required part of the accounting student curriculum. An important element of this approach is to select course content from these other academic areas that would have a high likelihood of being incorporated into the life long learning pattern of the accounting student. Actively encouraging and rewarding accounting faculty to collaborate with such endeavors would also contribute to the success of this approach. The question then is which area(s) of academia would be the most likely candidate for such collaboration.

The purpose of this paper is to introduce into the accounting literature the results of an emerging body of research that suggests arts education can enhance or help in the development of many of the qualities listed above as important to accountants. Furthermore, the arts can provide personal fulfillment and satisfaction, and thus provide an inherent motivation for life long learning. Thus based on the research to be discussed in this paper, it may be argued that the most productive venue to follow with respect this proposition is collaboration with the arts.

\section{The case for arts education}

\section{Involvement in the arts aids academic success}

In a recent address, the Secretary of Education made the following statement: "As the researchers discovered, learning in the arts can not only impact how young people learn to think, but also how they feel and behave." A growing body of research that suggests learners can attain to higher levels of achievement through their engagement with the arts. For example, a recent research project by Catterall, Chapleau, and Iwanaga (1999) reports that sustained involvement in music and theater was highly correlated with success in math and reading, respectively. The evidence that supports the argument that the arts have non-arts outcomes suggests accounting students might benefit from the non-arts outcomes of arts involvement, e.g., does involvement in the arts make for better accounting students, and ultimately, better professional accountants? If so, than the arts should be a required part of the educational requirements for accounting students in a way that is much more significant than merely requiring enrollment in an 'arts appreciation class.' This section of the paper reviews recent research that suggests accounting students might benefit from arts involvement, particularly, involvement in music and theatre.

\footnotetext{
${ }^{1}$ A Message from the Secretary of Education, Richard Riley, introducing a report compiling the results of seven major research studies. The study, Champions of Change: The Impact of the Arts on Learning, was released October 22, 1999 at the Arts Education Partnership Meeting in Washington, D.C.
} 


\section{Music improves mathematics achievement}

Based on a 10 year longitudinal study of 25,000 high school students in American secondary schools, Catterall, Chapleau, and Iwanaga (1999) report that students with a consistent and sustained high level of involvement in instrumental music show significantly higher levels of math proficiency by grade 12 . In addition, they report absolute differences in measured mathematics proficiency increased over time between students consistently involved in instrumental music and those students not involved in instrumental music. Another substantive finding of their study was that these results were true for students from low socio-economic status backgrounds as well.

An accumulation of studies over the past several years have reported that certain types of musical experiences seem to effect cognitive functions of students. Catterall, et al (1999) argue that this is because learning to read music and associate musical notation with abstract concepts of time, rhythm, and pitch involve forms of mathematical reasoning. Catterall et al state this is due to

"...the fractional senses of different musical notes (whole notes, half notes, and so on), the relative distances of notes within scales, the perfect doubles and halves in the pitch frequencies of octaves, and even the relation among dynamics within a musical passage."

Catterall et al go discuss other studies that have reported a variety of positive significant relationships between mathematics achievement and musical performance such as: (1) sight-singing and arithmetic, algebra and geometry; (2) pitch and arithmetic; and (3) tonal relationships and arithmetic and algebra (Klinedinst, 1991). BarnesJames (1991) report that the correlation between math grades and music theory grades for secondary students is strongest when the mathematics taught is of a more elementary nature and the numerical relationships are simple.

The application of the benefits of the sustained study of music to accounting should be obvious since accounting is based upon mathematics of an elementary nature with relatively simple numerical relationships. The basic accounting equation, for instance, is a simple algebraic formula of assets equals liabilities and owners equity. The double entry system of accounting depends upon the simple mathematical relationship of the left side of an equality always must equal the right side of an equality. The basic formula for an income statement is a simple algebraic expression as well: revenues minus expenses equals profit. Furthermore, the basic mathematical manipulations in accounting are of an elementary nature: addition, subtraction, and multiplication. Thus, the hypothesis is that there should be a positive and pronounced correlation between the sustained study of music and improved performance in accounting by accounting students because of the nature of accounting. Students who pursue sustained involvement in music should do better, on average, than students who do not pursue music involvement.

\section{Music develops creativity}

Another quality that the above commissions on improving accounting education stressed as important for new accountants is the capacity for creative thinking. For example one of the 3 qualities listed in 1989, the (then) largest 8 international accounting firms in the US as essential to entry level accountants was (1) intellectual skills (e.g., creative (emphasis added) problem solving and dealing with unfocused facts and ethical issues) (Perspectives, 1989).

Music education may assist with the capacity for creative thinking in at least two ways, because, music requires (1) creative problem solving and dealing with unfocused facts, i.e., interpretation, and (2) creative thinking in the composition of music.

The study of music develops creativity by the act of interpreting music. Interpretation of music is the process of decoding symbols into sounds. The initial step of this process is to look carefully at the small details. According to Christiani (1985), musical, artistic playing involves attention to the small intricacies of music. As the notes are being learned, they must also be phrased in much the same way as an author carefully words his sentences 
to have the greatest effect. During this phase, the dynamics are incorporated. Music can be loud, soft, or anywhere between. Based on the musical symbols and the era in which the piece was written, the musician will interpret the style in which the piece should be played. Some pieces are smooth while others pieces can be fast or slow, gentle or thunderous, harmonious or dissonant. Music portrays and delivers messages or stories, which must be interpreted by the musician so the listener can grasp the meaning behind the music. The informed reader cannot help but see the parallels to the accounting profession. Accounting information must be interpreted to be properly understood. The need to be able to successfully interpret the detailed information and yet still see the larger picture that is being portrayed is a similar skill to the musician's skill of presenting music to an audience. The accountant must be able to interpret the financial information about a business such that the information is useful in portraying the information in a way that aids a decision maker with a particular decision context.

Another way in which music develops creativity is through music composition. Christiani (1985) comments, "The composer is...the conceiver of ideas." According to Taylor, the most advanced level of creativity is that of coming up with a new thing (Taylor quoted. in Shutter 1968). Composing fits his definition well. The casual student of music may never compose an entire piece, but nearly every music student makes up tunes or harmonizes a melody from time to time. Composing and interpreting music will challenge one's creative abilities. Creativity is a trait much needed in the accounting profession. This trait is used in writing, speaking, problem solving, and many other areas of accounting. In addition, accountants are often called upon to make sense of oft-times unfocused facts, requiring the ability to view the facts in new and innovative perspectives similar to the arrangement and composition of music. Thus accounting students who have had sustained and continuous training in music will be much better prepared than students who have not had this exposure to creativity.

\section{Music promotes life long learning (self discipline)}

Music training may also help accounting students' academic performance and subsequent job performance because music training generally tends to increase self-discipline, a characteristic necessary not only for success in school but also for success in life. According to Lehman (1993), American businesses are looking for selfdisciplined, cooperative workers, qualities that the study of music will to develop. Successful accounting professionals did not suddenly become disciplined after graduation; they learned discipline during the long years of school. According to Miller and Coen (1994), many students have stated that a major contributor to developing selfdiscipline and the doggedness to attain a goal in spite of numerous odds has been the study of music in their lives. Music develops self-discipline, at least in part, through the daily sessions in the practice room. To play a piece well, it must be practiced on a daily basis. Often, several weeks or months of hard work may be necessary to learn a single piece. Higson (1991) points out how important detailed accuracy of notes, fingering, dynamics, technique, phrasing, and tempo markings are during each practice session. The discipline that practice requires will carry over into the accounting arena as well, since accounting, similar to music, is a multi-faceted and detail-oriented task. Some examples of the important details important to accounting include behavior of costs and revenues, classification of costs and revenues, dates, amounts, terms, and useful life. Developing an understanding and appreciation for the importance of the many faceted nature of each piece of accounting information is as important to an accounting student as attention to the detail of music is to a student of music.

\section{Music increases multi-level thinking}

The playing of music requires the brain to process many pieces of information simultaneously. Thus, music may assist the accounting student by increasing multi-level thinking skills, which are related to dealing with unfocused facts and logical reasoning. According to Martin (1995), on the 1993 S.A.T. test, students involved in music scored an average of nineteen points higher than students lacking musical training. This example is only one of several that show "a pattern of increasing gap" in the score of musicians and non-musicians. The results of this test demonstrate the value of music education.

Multi-level thinking is enhanced during the playing of music since the mind is coordinating many processes at once. Bodily action is coordinated, between the eyes, the fingers, the hands, the feet, the lungs, and in some cases the embouchure. Next, the mind simultaneously reads notes, phrase marks, and dynamics. Eric Oddleifson says that 
while playing music the 'mental capacities [are being used] in a very intensive and broad way' (Oddleifson quoted. in Van Tuyl 1991). Martin (1995) has compared reading music to reading a foreign language (Cooper quoted in Shutter 1968). The mind must translate the many symbols in the musical score into usable data. The usable data is then turned into audible music. Thus, the playing of music will enable the mind to assimilate and organize large amounts of data at a time. This multi-level thinking will be a great benefit to accounting students. The present day business world is experiencing an explosion of information, thus it is becoming more and more important that accountants be able to deal with large amounts of data, including unfocused facts. The accountant must be able to logical reason or sift through this explosion of information. Music research would suggest that music education has the potential to enhance this quality that is viewed as desirable in new accountants.

\section{Theatre benefits language skills}

Research results from Catterall et al also suggest that theatre may be beneficial to students by its correlation with language skills. In their study, Catterall et al reports that involved high school students outscored non-involved high school students on reading proficiency. Their time series data also indicated that this proficiency gap increased by the time the students had reached the $12^{\text {th }}$ grade. Theatre is a language-rich environment including reading, learning, and memorizing lines.

The implications for gains for accounting students is clear since reading proficiency is important for both verbal and written reports. If theatre involvement assists in this proficiency, than accounting students would benefit from involvement in theatre in a continuous manner.

\section{Theatre may assist personal and social development}

Other researchers have argued that involvement in theatre may assist in personal and social development. Purported benefits occur in areas such as group interaction, discipline, language usage, self-esteem, and movement skills (Jackson 1993). However, the strength of the evidence tends to be weak (Catterall et al 1999).

In addition to strong evidence as to language skill proficiency for involved students in theatre, Catterall also reported some positive correlations between involved students and their self-concept, empathy and tolerance for others.

Similar to music involvement, involvement in theatre may have some positive gains for accounting students in language skills as well as interpersonal skills. However, in both music and theatre, the key to the proficiency gains appears to be continuous rather than incidental involvement in the arts. Providing an incentive for accounting students to maintain such an involvement, i.e., required, as part of the 150-hour rule would appear to be necessary to appropriate the benefits. An obvious question might be how much involvement should be expected? At a minimum, it would appear the involvement should be on a continuing basis rather than a single course requirement. Since most music and theatre departments offer coursework in 1 credit hour segments, it would be feasible to require 1 course/semester, or per academic year. These 1 credit hour courses would allow the sustained and continual involvement required for continuing arts involvement yet it would not interfere with the other core requirements for an accounting degree.

\section{Conclusion}

The above research suggests that accounting students are uniquely suited to benefit from music education. Although no data dealing directly with accounting students and the arts has been collected to date, the above research would suggest that accounting students with continuing and intensive music education are likely to experience positive and increasing gains from such involvement.

The above research also suggests that students may self-select into accounting because they are deficient in certain desirable attributes and want to avoid exposure of such weaknesses. If so, requiring some level of continuing involvement in the arts as part of the 150 hour requirement would help students to overcome such deficiencies. Such 
involvement would be preferred over trying to incorporate such training in the accounting coursework due to the comparative advantages and synergisms the field of Arts education has in this area both in terms of the actual curriculum and the training of the faculty. In addition, involvement in the arts can be personally rewarding and provide a venue for life-long learning for the accounting student that is inherently rewarding. Such involvement would also broaden the accounting student's perspectives and outlook on life providing improved interpersonal skills that would be useful in the workplace.

The above research would also suggest that adjusting the way the accounting profession is perceived is important in attracting students with the qualities that are in demand in the accounting profession. Thus, accounting academics should actively seek to change the image of the accountant and also to consider recruiting students with existing involvement in music.

Finally, studying music will provide students not only with academic advantages but also with musical enjoyment. "Music instruction contributes to learning the basic skills of reading, writing, and arithmetic; develops mental discipline and, in fact, teaches how to learn; promotes problem-solving abilities and higher-order thinking skills" (Lehman 1993), and provides benefits and pleasure throughout a person's lifetime.

Future avenues for research in this area would include studies on current accounting students' music background and the relationship of prior music training to current performance in accounting courses, experimental studies of the effect of music education on performance on various accounting related problems and decision scenarios, and longitudinal studies of accounting students to determine the long-range impact of music training on success in accounting. Studies of school level initiatives to bring arts integration into the 150-hour curriculum would also be of benefit.

This area of research has the potential to offer explanations of possible antecedents that may enhance the development of many of the qualities listed above as important to the accountants of the 21 st century. If this were in fact the case, it would suggest that the accounting academic community should seriously consider how they might capitalize on these reported positive effects of music education.

\section{References}

1. American Accounting Association (AAA), Committee on the Future Structure, Content, and Scope of Accounting Education (The Bedford Committee) (1986). "Future Accounting Education: Preparing for the Expanding Profession," Issues in Accounting Education, Spring, vol. 1, no. 1. 168-195

2. Accounting Education Change Commission (1990). "Objectives of Education for Accountants: Position Statement Number One," Issues in Accounting Education, Vol. 5, No. 2, 307-312.

3. Arthur Anderson \& Co., Arthur Young, Coopers \& Lybrand, Deloitte Haskins \& Sells, Ernst \& Whinney, Peat Marwick Main \& Co., Price Waterhouse, and Touche Ross, (1989). Perspectives on Education: Capabilities for Success in the Accounting Profession, April.

4. $\quad$ Ashley, Douglas (1993). Music Beyond Sound. New York: Peter Lang.

5. Austin, James (1996). "Future Classroom Teacher's_Ability, Self-Perceptions, and Attributional Responses to Failure in Music: Do Music Fundamentals Classes Make a Difference?” Online. Internet. 1 October.

6. Bowman, Edward M (1911). Master Lessons in Pianoforte Playing. Philadelphia: Theodore Presser Co.

7. Catterall, James S., and Richard S. Chapleau and John Iwanaga. (1999) "Involvement in the Arts and Human Development: General Involvement and Intensive Involvement in Music and Theater Arts," Champions of Change: The Impact of the Arts on Learning. Edward B. Fiske, ed.

8. Christiani, Adolph E. (1985). The Principles of Expression in Pianoforte Playing. Philadelphia: Harper and Brothers.

9. Covington, Kate (1996). "The Arts in Education--An Absolute Necessity." The College Music Society. Online. Internet. 1 October.

10. Geary, William T., and Rooney, Cynthia J. (1993). "Designing Accounting Education to Achieve Balanced Intellectual Development." Issues in Accounting Education, Vol. 8, No. 1, pp.60-70. 
11. Higson, James (1991). Amateur at the Keyboard: A Practice and Study Guide for the Nonprofessional Pianist. Jefferson, NC: McFarland and Company, Inc.

12. International Federation of Accountants (1994). 2000 and beyond: A Strategic Framework for Prequalification Education for the Accountancy Profession in the Year 2000 and Beyond.

13. Jackson, Tony. (1993). Learning Through Theatre: new perspectives on theater in education. Second edition. London: Routledge.

14. Lehman, Paul R. (1993). "Why Your School Needs Music.” Arts Education Policy Review. Mar./Apr: 3034.

15. Martin, Matt (1995). “S.A.T.'s and Music.” American Music Teacher. Apr/May: 16-17.

16. Miller, Allan and Dorita Coen (1994). "The Case for Music in the Schools." Phi Delta Kappan. Feb: 45961.

17. Schmitz, Robert E (1935). The Capture of Inspiration. Los Angeles: Will A. Kristler Company.

18. Shutter, Rosamund (1968). The Psychology of Musical Ability. London: Methuen and Co. Ltd., 1968.

19. Stanga, Keith J., and Ladd, Robert T. (1990). "Oral Communication Apprehension in Beginning Accounting Majors: An Exploratory Study." Issues in Accounting Education, vol. 5, no. 2, pp.180-194.

20. Van Tuyl, Laura (1991). "Arguing for Arts Education.” Christian Science Monitor 83. 1 Apr: 12-14.

21. Warnock, K. (1996). "Socialization or Self-Selection? Some Evidence of the Narrowness of Aspiring Accountants," working paper, University College Galway, Ireland. 